\title{
PRELIMINARY PHYTOCHEMICAL ANALYSIS AND IN VITRO ANTIOXIDANT ACTIVITY OF ARAUCARIA COLUMNARIS BARK PEEL AND COSMOS SULPHUREUS FLOWERS
}

\author{
KRISHMA M. JADAV ${ }^{*}$, K. N. NINGE GOWDA ${ }^{2}$ \\ 1,2Department of Apparel Technology and Management, Bangalore University, Bangalore 560001, India \\ Email: krishma.jadav@gmail.com
}

Received: 28 Jan 2017, Revised and Accepted: 20 Apr 2017

\section{ABSTRACT}

Objective: Four different extracts of Araucaria columnaris (bark peel) and Cosmos sulphureus (flowers) were screened for their phytochemical composition, and free radical scavenging activities.

Methods: DPPH method was used to test the antioxidant activity for extracts.

Results: Among the different extracts tested, the methanol extract of both the plant species showed significant radical scavenging activities. Phytochemical analysis of the extracts revealed that the radical scavenging activities might be due to the presence of flavonoids, tannins and phenolic compounds.

Conclusion: The results obtained suggest that Araucaria columnaris (bark peel) and Cosmos sulphureus (flowers) could be exploited in the treatment of various diseases like cancer, cardiovascular diseases and infection diseases.

Keywords: Cosmos sulphureus, Araucaria columnaris, Antioxidant activity, DPPH, Phytochemicals, Radical scavenging

(C) 2017 The Authors. Published by Innovare Academic Sciences Pvt Ltd. This is an open access article under the CC BY license (http://creativecommons.org/licenses/by/4.0/) DOI: http://dx.doi.org/10.22159/ijcpr.2017v9i4.20967

\section{INTRODUCTION}

Medicinal plants are resources of new drugs and many of the modern medicines are produced indirectly from plants [1]. In the last years, interest in medicinal plants as an alternative to synthetic drugs is more and more increasing because of safety concerns, particularly against oxidative stress [2, 3]. Oxidative stress is potential when there is an imbalance between ROS (Reactive Oxygen Species) production and cellular antioxidant activity [4]. Oxidative stress is implicated in over hundred human disease conditions, such as cancer, cardiovascular diseases, aging and neurological disorders. This free radical induced oxidative stress can be prevented by the intake of sufficient amount of antioxidants [5]. Antioxidants are molecules that are capable of neutralizing the harmful effects of the ROS through the endogenous enzymatic defence system such as the superoxide dismutase (SOD), glutathione peroxidase (GPX) and catalase (CAT) in human system [6, 4]. Several studies have shown that the mechanism underlying polar antioxidant involves reactions with the hydroxyl $(\mathrm{OH})$ group present in phenolics. Indeed, phenolics are composed of one or more aromatic rings bearing one or more hydroxyl groups and are therefore potentially able to quench free radicals by forming stabilized phenoxyl radicals and most of the current antioxidants isolated so far from flowering plants are simple phenolic compounds which owe their properties to the mere fact that their aromatic hydroxyl moieties react with free radicals [7].

Research has quite convincingly shown that foods and herbs rich in antioxidants reap health benefits. Foods may possibly enhance antioxidant levels because foods contain a lot of antioxidant substances [8]. Potential sources of antioxidant compounds have been found in several types of plant materials such as vegetables, fruits, leaves, oilseeds, cereal crops, barks and roots, spices and herbs, and crude plant drugs [9]. Natural products, mainly obtained from dietary sources provide a large number of antioxidants. Phytoconstituents are also an important source of antioxidant and capable to terminate the free radical chain reactions $[10,11]$.

Araucaria columnaris belongs to the family Araucariaceae and genus Araucaria. It is distributed throughout the New Caledonia and Peshawar. It is commonly used as an ornamental plant all around the world $[12,13]$.
Cosmos sulphureus Cav. is a member of the family Asteraceae [14]. It is cultivated as an ornamental plant or it has been found as growing wild weeds along the roadsides and other undisturbed areas. Cosmos flowers are available in three different colours, orange, yellow and red. Flower capitulum composed of the disc and ray florets (7-8 petals like), straight and long-stalked. The height of the plant is $90-120 \mathrm{~cm}$ and has compound leaves. Flowering season is October to December [15]. The present study was undertaken to investigate the phytochemical and antioxidants properties of bark peel extract of Araucaria columnaris and flower extracts of Cosmos sulphurous with a view to assess the potentials of both the plants as a source for phenolic antioxidants.

\section{MATERIALS AND METHODS}

\section{Plant material}

The bark peel of Araucaria columnaris was collected from Lalbagh Botanical Garden, Bangalore and Cosmos sulphurous flowers were collected from different Botanical gardens situated in and around Bangalore. Both the plant materials collected were air-dried and ground to fine powder.

\section{Extraction}

Successive solvent extraction [16, 17] procedure was adopted for the preparation of various extracts Araucaria columnaris and Cosmos sulphureus. The powdered plant materials were subjected to successive extraction using Soxhlet apparatus with solvents in their ascending order of polarity. The solvents used were petroleum ether (60-80 $\left.{ }^{\circ} \mathrm{C}\right)$, chloroform, methanol and distilled water. The extracts were filtered using Whatman no. 1 and further dried by using rotary evaporator until semi-solid is obtained.

\section{Preliminary phytochemical screening}

The phytochemical screening was carried out using standard procedures [18]. The tests for phytochemical screening include:

\section{A. Tests for Carbohydrates}

i. Benedict's test: Equal volumes of Benedict's reagent and test solution were mixed in a test tube and heated in boiling water bath 
for $5 \mathrm{~min}$. Appearance of green, yellow or red indicated the presence of carbohydrates depending on the amount of reducing sugar present in test solution.

\section{B. Test for Proteins}

i. Million's test: $3 \mathrm{ml}$ of test solution was mixed with $5 \mathrm{ml}$ of Million's reagent. White ppt. forms; when made warm turns brick red or ppt. dissolves giving red coloured solution indicating the presence of proteins.

\section{Tests for Amino acids}

i. Tyrosine test: $3 \mathrm{ml}$ of test solution was heated with 3 drops of Million's reagent. Dark red colour formed shows the presence of Amino acids.

\section{Tests for Fats and Oils}

i. Filter paper test: Filter paper was treated with the test solution and dried. Permanent oil stain on the filter paper indicated the presence of Fats and Oils.

\section{E. Tests for Steroid}

i. Liebermann's reaction: $3 \mathrm{ml}$ of test solution was mixed with $3 \mathrm{ml}$ acetic anhydride. Heated and cooled. On addition of few drops of $\mathrm{H}_{2} \mathrm{SO}_{4}$, the appearance of blue colour indicated the presence of steroids.

\section{F. Tests for Volatile oils}

i. Hydro distillation method: The test solution was hydrodistillated. Volatile oil was separated from the distillate. The filter paper was treated with volatile oil and dried. The filter paper is not permanently stained with volatile oil.

\section{G. Tests for Glycosides}

i. Liebermann's test: $3 \mathrm{ml}$ of test solution was mixed with $3 \mathrm{ml}$ acetic anhydride. Heated and cooled. On addition of few drops of $\mathrm{H}_{2} \mathrm{SO}_{4}$, appearance of blue colour indicated the presence of Glycosides

\section{H. Tests for Saponins}

i. Foam test: Persistent foam was observed when test solution was shaken vigorously with water indicating the presence of saponins.

\section{Test for Coumarins}

i. Odour test: Aromatic odour indicated presence of coumarin glycosides

ii. Alkalinity test: Alcoholic extract when made alkaline showed blue or fluorescence indicating the presence of coumarins.

\section{J. Tests for Flavonoids}

i. Sulphuric acid test: On addition of sulphuric acid ( $66 \%$ or $80 \%$ ) flavones and flavonols dissolve into it giving a deep yellow solution. Chalcones and aurones gave red or red-bluish solutions. And orange to red colours indicated the presence of Flavanes.

ii. Lead acetate solution test: to a small quantity of residue, lead acetate solution was added. Yellow coloured ppt. formed indicated the presence of flavonoids.

\section{K. Tests for Alkaloids}

i. Tannic acid test: Test solution treated with tannic acid solution gave buff coloured ppt. indicating the presence of alkaloids.

\section{Tests for Tannins and Phenolic compounds}

i. $\mathbf{5 \%} \mathbf{F e C l}_{3}$ test: $\mathrm{To} 2-3 \mathrm{ml}$ of aqueous or alcoholic extract, few drops $\mathrm{FeCl}_{3}$ (5\%) was added. Deep blue-black colour observed indicated the presence of Tannins and Phenolic compounds.

\section{Determination of antioxidant activity (DPPH assay)}

Radical scavenging activity of the extracts was determined by measuring the decrease in absorbance of 2, 2-Diphenyl-1picrylhydrazyl radical (DPPH•) at $517 \mathrm{~nm}$ [19]. The DPPH assay is a widely used method to evaluate the ability of antioxidants [20] to scavenge free radicals which are known to be a major factor in biological damages caused by oxidative stress. This assay is known to give reliable information concerning the antioxidant ability of the tested compounds [21-23]. This method is based on the ability of DPPH radical to react with hydrogen donor species such as phenolics and flavonoids present in the extracted material. Upon receiving a proton from the donor species it loses its color and becomes yellow. As the concentration of phenolic compounds increases, their DPPH radical scavenging activity also increases [24]. The crude extracts were weighed and dissolved in DMSO (10 $\mathrm{mg} / \mathrm{ml}$ ). This was considered as pure sample extract for testing the antioxidant property. $0.3 \mathrm{mmol}$ solution of DPPH was prepared in $100 \%$ methanol. To $1 \mathrm{ml}$ of this solution, three different concentrations $100 \mu \mathrm{l}, 300 \mu \mathrm{l}$ and $500 \mu \mathrm{l}$ of sample extract and standard solution (Ascorbic acid) were added separately. The final volume was made up to $4 \mathrm{ml}$ by adding $100 \%$ methanol to each sample mixture and also for a standard solution (Ascorbic acid). The same reaction mixture without the extracted sample but with an equivalent amount of standard phosphate buffer was taken as control. All the sample mixtures and control were shaken thoroughly and kept in dark at room temperature for $30 \mathrm{~min}$. The absorbance of the reaction mixtures was measured at $517 \mathrm{~nm}$ [25]. The radical scavenging activities were expressed as a percentage of inhibition and calculated according to the following equation.

$$
\begin{gathered}
\text { DPPH radical scavenging activity }(\%)=\left[\left(A_{\text {control- }}-A b s_{\text {sample }} /(A b s\right.\right. \\
\text { control })] \times 100
\end{gathered}
$$

Where $A b s_{\text {control }}$ is absorbance control and $A b s_{\text {sample }}$ is absorbance test sample.

\section{RESULTS AND DISCUSSION}

\section{Preliminary phytochemical screening}

The phytochemical analysis conducted on Araucaria columnaris and Cosmos sulphureus extracts revealed the presence of proteins, coumarins, saponins, amino acids, flavonoids, tannins, and phenolic compounds (table 1 and table 2). These phytochemical compounds are known to support bioactive activities in medicinal plants and thus responsible for the antioxidant activities of this plant extract used in this study.

\begin{tabular}{|c|c|c|c|c|c|c|c|}
\hline Phytochemical constituents & Tests & Blank & Control & Petroleum ether & Chloroform & Methanol & Aqueous \\
\hline Carbohydrates & Benedict's test & - & + & - & - & - & - \\
\hline Proteins & Million's test & - & + & - & - & + & - \\
\hline Amino acids & Tyrosine test & - & + & - & - & - & - \\
\hline Fats and oils & Filter paper test & - & + & - & - & + & + \\
\hline Steroids & Liebermann-Burchard Test & - & + & - & - & - & - \\
\hline Glycosides & Liebermann's test & - & + & - & - & - & - \\
\hline Saponins & Foam test & - & + & - & - & - & + \\
\hline \multirow[t]{2}{*}{ Coumarins } & Odour test & - & + & - & - & - & + \\
\hline & Alkalinity test & - & + & - & - & - & - \\
\hline \multirow[t]{2}{*}{ Flavonoids } & $\mathrm{H}_{2} \mathrm{SO}_{4}$ test & - & + & - & - & ++ & + \\
\hline & Lead acetate solution test & - & + & - & - & ++ & + \\
\hline Alkaloids & Tannic acid test & - & + & - & - & - & - \\
\hline Tannins and phenolic compounds & $5 \% \mathrm{FeCl}_{3}$ test & - & + & - & - & ++ & + \\
\hline
\end{tabular}

Table 1: Results of the qualitative test for preliminary phytochemical analysis of Araucaria columnaris (bark peel) extracts

$+++($ High $),++($ Moderate $)+($ low $)$ and-(Nil) 
Table 2: Results of the qualitative test for preliminary phytochemical analysis of Cosmos sulphureus (flower) extracts

\begin{tabular}{|c|c|c|c|c|c|c|c|}
\hline Phytochemical constituents & Tests & Blank & Control & Petroleum ether & Chloroform & Methanol & Aqueous \\
\hline Carbohydrates & Benedict's test & - & + & - & - & - & - \\
\hline Proteins & Million's test & - & + & - & - & - & - \\
\hline Amino acids & Tyrosine test & - & + & - & - & - & + \\
\hline Fats and oils & Filter paper test & - & + & - & - & + & + \\
\hline Steroids & Liebermann-Burchard Test & - & + & - & - & - & - \\
\hline Glycosides & Liebermann's test & - & + & - & - & - & - \\
\hline Saponins & Foam test & - & + & - & - & - & + \\
\hline \multirow[t]{2}{*}{ Coumarins } & Odour test & - & + & - & - & - & - \\
\hline & Alkalinity test & - & + & - & - & - & - \\
\hline \multirow[t]{2}{*}{ Flavonoids } & $\mathrm{H}_{2} \mathrm{SO}_{4}$ test & - & + & - & - & +++ & ++ \\
\hline & Lead acetate solution test & - & + & - & - & +++ & - \\
\hline Alkaloids & Tannic acid test & - & + & - & - & - & - \\
\hline Tannins and phenolic compounds & $5 \% \mathrm{FeCl}_{3}$ test & - & + & - & - & ++ & + \\
\hline
\end{tabular}

+++(High),++(Moderate)+(low) and-(Nil)

\section{Determination of antioxidant activity (DPPH assay)}

The in vitro antioxidant assay of both the plant extracts (fig. 1 and fig. 2) reveals significant antioxidant potential compared with standard Ascorbic acid. The methanol extracts of both the plants Araucaria columnaris and Cosmos sulphurous showed highest antioxidant activity. The percentage inhibition of Araucaria columnaris and Cosmos sulphureus at the concentration of $500 \mu \mathrm{l}$ were $90.37 \%$ and $89.87 \%$ respectively, compared to ascorbic acid (94.05\%). The extracts showed increased antioxidant activity with the increase in concentration $(\mu \mathrm{l})$ of the extracts.

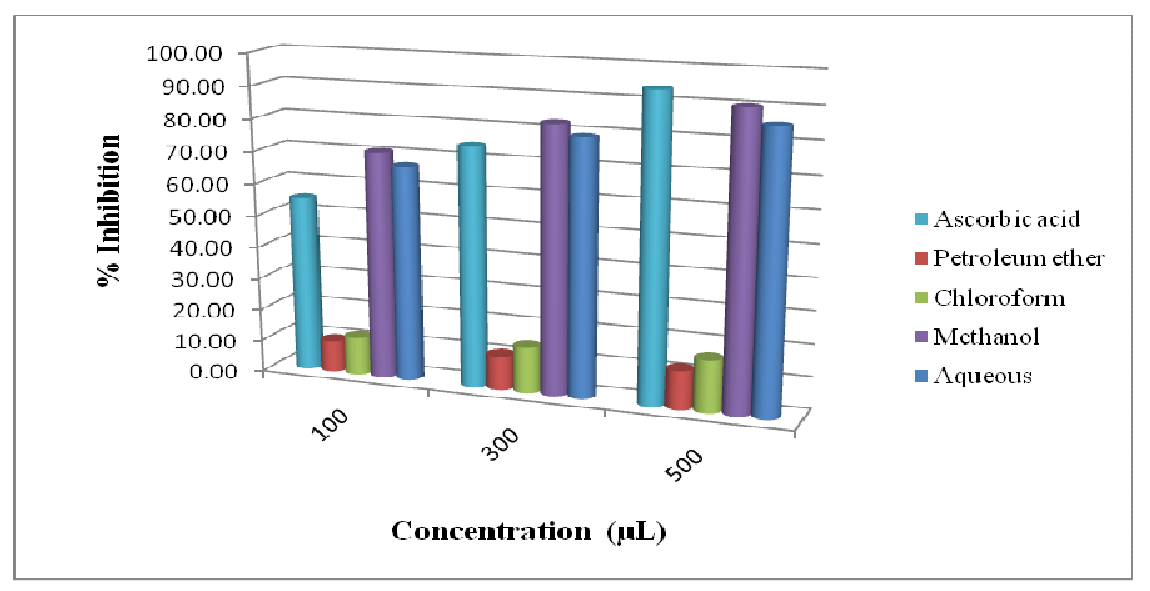

Fig. 1: Antioxidant properties of Araucaria columnaris plant extract in comparison with standard ascorbic acid as determined with DPPH method

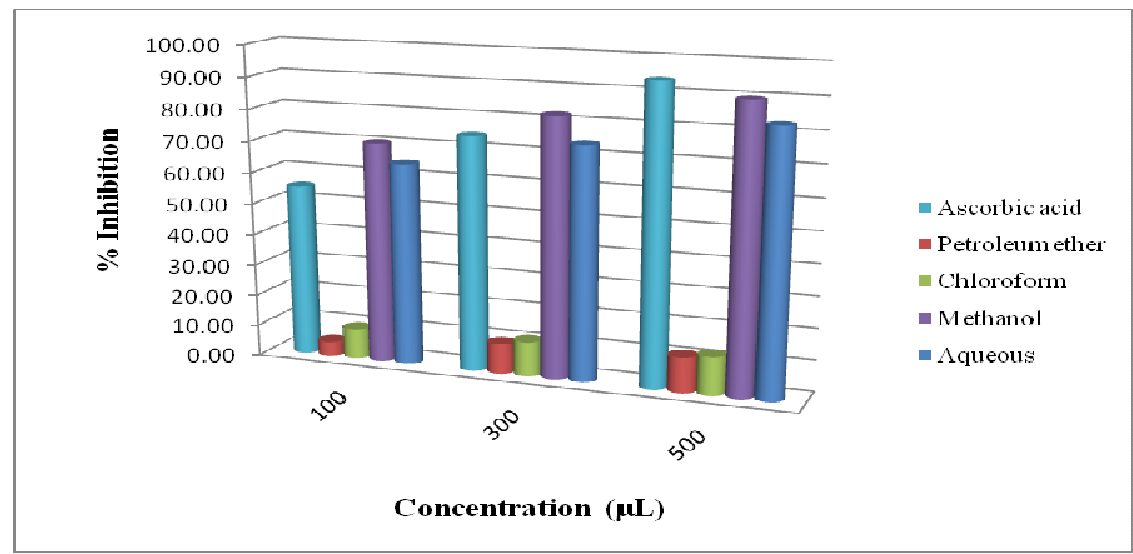

Fig. 2: Antioxidant properties of Cosmos sulphureus plant extract in comparison with standard ascorbic acid as determined with DPPH method

\section{CONCLUSION}

As antioxidants play a vital role in fighting against many diseases, especially those that are due to oxidative stress, it is important to identify which natural plants are effective in fighting against the free radicals. Based on the results obtained, the radical scavenging activity is concentration-dependent, as it increases when the concentration changes from $100 \mu \mathrm{l}$ to $300 \mu \mathrm{l}$ to $500 \mu \mathrm{l}$. The investigation confirms the in vitro antioxidant potential of solvent extracts of Araucaria columnaris and Cosmos sulphureus, with results 
comparable to those of the standard compound ascorbic acid and can, therefore, be proposed as new potential sources of natural additives for the food and/or pharmaceutical industries. The phytochemical screening revealed the presence of flavonoids, tannins and phenolic compounds in methanol and aqueous extracts of both the plant species. However, the components responsible for the antioxidant activity of the extracts were not identified and further work should be conducted to isolate and identify these bioactive compounds.

\section{CONFLICTS OF INTERESTS}

All authors have none to declare

\section{REFERENCES}

1. Hosseinzadeh S, Jafarikukhdan A, Hosseini A, Armand R. The application of medicinal plants in traditional and modern medicine: a review of thymus vulgaris. Int J Clinical Med 2015;6:635-42.

2. Bendiabdellah A, Dib MEA, Meliani N, Djabou N, Allali H, Tabti B. Preliminary phytochemical screening and antioxidant activities of solvent extracts from Daucuscrinitus desf, from Algeria. J Appl Pharm Sci 2012;2:92-5.

3. Oluwaseun AA, Ganiyu O. Antioxidant properties of methanolic extracts of mistletoes (Viscum album) from cocoa and cashew trees in Nigeria. Afr J Biotech 2008;7:3138-42.

4. Sarrafchi A, Bahmani M, Shirzad H, Rafieian-Kopaei M. Oxidative stress and Parkinson's disease: new hopes in treatment with herbal antioxidants. Curr Pharm Design 2016;22:1-9.

5. Pavithra GM, Siddiqua S, Naik AS, Prashith KTR, Vinayaka KS. The antioxidant and antimicrobial activity of flowers of Wendlandiathyrsoidea Olea dioica Lagerstroemia speciose and Bombaxmalabaricum. J Appl Pharm Sci 2013;3:114-20.

6. Aliyu AB, Musa AM, Ibrahim MA, Ibrahim H, Oyewale AO. Preliminary phytochemical screening and antioxidant activity of leaves extract of Albizia Chevalieri harms (Leguminoseaemimosoideae). Bayero J Pure Appl Sci 2009;2:149-53.

7. Lu Y, Knoo T, Wiart C. Phytochemical analysis and antioxidant activity determination on crude extracts of Melodinuseugeniifolus barks and leaves from Malaysia. Pharmacol Pharm 2014;5:773-80.

8. Sen S, Chakraborty R, Sridhar C, Reddy YSR, Biplab De. Free radicals, antioxidants, diseases and phytomedicines: current status and future prospect. Int Pharm Sci Rev Res 2010;3:91-100.

9. Kahkonen MP, Hopia AI, Vuorela HJ, Rauha JP, Pihlaja K, Kujala TS, et al. Antioxidant activity of plant extracts containing phenolic compounds. J Agric Food Chem 1999;47:3954-62.

10. Zheng W, Wang SY. Antioxidant activity and phenolic compounds in selected herbs. J Agric Food Chem 2001;49:5165-70.
11. Dragland S, Senoo H, Wake K, Holte K, Blomhoff R. Several culinary and medicinal herbs are important sources of dietary antioxidants. J Nutr 2003;133:1286-90.

12. Aslam MS, Choudhary BA, Uzair M, Ijaz AS. Phytochemistry of aerial parts of Araucaria Columnaris. J Appl Pharm 2014;6:114-20.

13. Aslam MS, Choudhary BA, Uzair M, Ijaz AS. Phytochemical and ethnopharmacological review of the genus araucaria-review. Trop J Pharm Res 2013;12:651-9.

14. Schlangen K, Miosic S, Thill J, Halbwirth H. Cloning, functional expression, and characterization of a chalcone 3-hydroxylase from Cosmos sulphurous. J Exp Botany 2010;61:3451-9.

15. Kumari S, Sidhu MC. Meiotic studies in Cosmos sulphureus cav. Chromosome Botany 2012;7:117-8.

16. Kokate CK, Khandelwal, Gokhale SB. Practical pharmacognosy. $2^{\text {nd }}$ d. Pune, India: NiraliPrakashan Pub; 1996.

17. Kokate CK, Purohit AP, Gokhale SB. Pharmacognosy. $4^{\text {th }}$ ed. Pune, India: NiraliPrakashan Pub; 2008.

18. Khandelwal KR, Sethi V. Practical pharmacognosy: techniques and experiments. 25th ed. Pune, India: NiraliPrakashan Pub; 2015.

19. Khadabadi SS, Deore SL, Baviskar BA. Quantitative chemical estimation. experimental phytopharmacognosy. $2^{\text {nd }}$ ed. Pune, India: NiraliPrakashan Pub; 2013.

20. Sahgal G, Ramanathan S, Sasidharan S, Mordi MN, Ismail S, Mansor SM. In vitro antioxidant and xanthine oxidase inhibitory activities of methanolic Swieteniamahagoni seed extracts. Molecules 2009;14:4476-85.

21. Grace-Lynn C, Darah I, Chen Y, Latha LY, Jothy SL, Sasidharan S. In vitro antioxidant activity potential of lantadene $a, a$ pentacyclic triterpenoid of lantana plants. Molecules 2012;17:11185-98.

22. Huang D, Ou B, Prior RL. The chemistry behind antioxidant capacity assays. J Agric Food Chem 2005;53:1841-56.

23. Parthasarathy S, Azizi JB, Ramanathan S, Ismail S, Sasidharan S, Said MIM, et al. Evaluation of antioxidant and antibacterial activities of aqueous, methanolic and alkaloid extracts from Mitragynaspeciosa (rubiaceae family) leaves. Molecules 2009;14:3964-74.

24. Porto CD, Calligaris S, Cellotti E, Nicoli MC. Antiradical properties of commercial cognacs assessed by the DPPH $\bullet$ test. J Agric Food Chem 2000;48:4241-5.

25. Shekhar TC, Anju G. Antioxidant activity by DPPH radical scavenging method of Ageratum conyzoides Linn. leaves. Am J Ethnomed 2014;1:244-9.

\section{How to cite this article}

- Krishma M Jadav, KN Ninge Gowda. Preliminary phytochemical analysis and in vitro antioxidant activity of Araucaria columnaris bark peel and Cosmos sulphureus flowers. Int J Curr Pharm Res 2017;9(4):96-99. 